UDC 811.111'276.2

DOI https://doi.org/10.32841/2409-1154.2020.45-2.29

\author{
Pylypei Yu. A., \\ Assistant at the Department of Romano-Germanic Philology and Translation \\ Bila Tserkva National Agrarian University
}

\title{
CHARACTERISTICS OF SLANG FORMATION: BLENDS, CLIPPINGS, REDUPLICATIVES
}

Summary. Language can be used both in oral and written forms based on their contexts. While from its context, language can be used in formal and informal situations. People usually use formal or standard language in formal context, while in informal context people usually use informal one. There are some kinds of language varieties that are used in informal context and one of them is slang. Long time ago, slang was mostly used by criminals, but now many communities make their own slang sayings. They create a lot of new words and modify standard words for internal using. This article we dedicate to the studying of the most frequent three types of the slang formation. We propose generative models for three types of extra-grammatical word formation phenomena appearing in English slang: Blends, Clippings, and Reduplicatives. Overall, the models reveal insights into the generative processes of word formation in slang - insights which are increasingly relevant in the context of the rising prevalence of slang and non-standard varieties. These word formation mechanisms are not only appealing from a linguistic standpoint in deepening our understanding of slang but also have applications spanning the development of rich conversational agents and tools like brand name generators.

Quite often slang words can be understood through the context, some cultural peculiarities, even if it is a newly created slang lexeme. Listener must always follow the hints that will help him figure out and decipher what is being said by the native speaker and not only. Because of the slang tendency usage spreads far and beyond the boundaries of the countries where English is official language.

Language itself consists of some parts, such as morphemes, words, sentences, etc. Each part has its own function and rule. People don't know where do actually those millions words come from. We as the users of language don't think about how a language is formed. The meaning of the new word form is influenced by the process of forming a word. This process is usually called word formation process.

Key words: slang, slang lexeme, word formation, blends, clippings, reduplicatives.

Problem statement. Nowadays slang is a form of language in general use that comprises of popular adaptation and reviewing of the existing words by constructing new words regardless the standards of scholastic and linguistic rules in the formation of words that is generally limited to social groups or specific groups.

The main goal of this article is to provide the main types of the word formation and to single out three dominant types of the slang formation respectively.

Findings and discussions. Communication is an important thing in human's life. Every time and everywhere people do it to make themselves clear. According to Oxford English dictionary, slang is defined as special form of a word that is usually used by people who have a low character. So we may conclude that slang is an informal language used by a particular group so the outsiders cannot understand the conversation that has another meaning from original word, and also slang is sometimes arranged from old words became the new word that neglect linguistics standards in the formation of words in general.

This research will take to account morphological studies conducted by some famous linguists. Morphology, in linguistics, is the study of the forms of words, and the ways in which words are related to other words of the same language. Formal differences among words serve a variety of purposes, from the creation of new lexical items to the indication of grammatical structure.

Morpheme is the smallest unit of the grammatical structure or the smallest part of the word. Morpheme is divided into two, namely: free morpheme and bound morpheme. The definition of a free morpheme according to Yule [5] is morpheme that can stand by themselves as single words.

This type of morphemes can be use without having to combine it first with another morpheme. On the contrary, bound morpheme is a morpheme that can be used or cannot appear in the sentence without combined it first with another morpheme. Yule defines bound morphemes as those forms that cannot normally stand alone and are typically attached to another form [5, p. 68]. Bound morphemes never occur in isolation, that is, are not regularly uttered alone in normal discourse. Such bound morphemes include prefixes, suffixes, infixes, subtractive, and some roots [3, p. 81]. For example, the affix -ly in the word locally is kind of bound morpheme.

Lexemes and words are linguistic units bigger than morphemes. Lexemes and words are two different terms. In general, we can say that lexemes are vocabulary items listed in the dictionary.

\begin{tabular}{|c|c|}
\hline Lexeme & Words \\
\hline Read & Reader, reading, reads \\
\hline Book & Books, booking, booked \\
\hline Sleep & Sleeps, sleeping, slept \\
\hline Eat & Eats, eating, ate, eaten \\
\hline
\end{tabular}

Formation of words is divided by the rules of word formation. In this research, the writer uses the theory of word formation from George Yule [5] to analyze the data. There are ten word formation processes according to Yule:

a. Acronym. Every acronym is an abbreviation because acronym is a shortened word or phrase. Acronyms are new words formed from the initial letters of a set of other words that pronounced as new single words, as in NATO, NASA or UNESCO [5, p. 58]. Actually, there is another type of abbreviation that is Intialism, this type is the shortening from the initial letters of each word and can be read with spelling of each letter [2, p. 210]. The examples are, BFF for Best Friends Forever, USA for United State of America [1]. 
b. Back formation is the process when a word of one type (usually a noun) is reduced to form a word of another type (usually a verb) [5, p. 56-57]. A good examples for back formation are, the noun television became the verb televise, donate from donation, housekeep from housekeeper, etc [1].

c. Blending. The word formation process in which there are two root words merge into one. According to Yule [5, p. 55], blending is the combination of two separate forms to produce a single new term. Blends are similar to compounds but parts of the words that are combined are deleted and so they are "less than" compound. Usually, blending is only taking the beginning of one word and joining it to the end of the other word. Examples: smog from the word smoke and fog, brunch from breakfast and lunch, motel from motor and hotel [1].

d. Borrowing. Yule said that borrowing is the taking over of words from other languages [5, p. 54]. Borrowing actually is the process of borrowing words from foreign languages. Hatch and Brown said that every language is borrowing from other languages [2, p. 170]. Throughout history, the English language has adopted of words from other languages, including Arabic, French, Dutch, Italian, German, and so on [5, p.54]. Example of borrowing words: in Japan, besiboru, is borrowing words from English which means 'baseball' [1].

e. Coinage is the invention of totally new terms in a word $[5$, p. 53]. Hatch and Brown [2, p. 175] define coinage as a process when a new word is needed but no exact word to express. Coinage happens when a new word is needed. The most typical sources are invented trade names for commercial products that become general terms for any versions of that product. Examples: 'kleenex' for tissue, 'Indomie' for instant noodles, 'moolah' for money [1].

f. Compounding. According to Yule [5, p. 55], compounding is a joining of two separate words to produce a single form. Some claim that compounding is the result and the process of merging the basic morphemes, whether free morpheme or bound morpheme, thus forming a construction that has a different or a new lexical identity. Common English compounds are bookcase, doorknob, fingerprint, sunburn, textbook, etc [1].

g. Conversion is a process of a changing the function of a word without any reduction [5, p. 57]. Conversion is process which allows us to create additional lexical items out of those that already exist. This process usually changing a noun becomes a verb. For example, nouns such as bottle, butter, vacation have come to be used, through conversion, as verb: We bottled home-brew last night; Have you buttered the toast; they're vacationing in Florida [1].

h. Clipping process happens when a word of more than one syllable is reduced to a shorter form. Clipping is one way in which we change the words. We may shorten dormitory to dorm, we use the longer term if the situation is formal and use the shorter one if the situation is informal. Other common examples are phone from telephone, ad from advertisement, condo from condominium, flu from influenza [1].

i. Derivation as a process when one word added by affixes and form in which meaning and categories are different from the basic word. This process is the most common word formation process to be found in the production of new English words. This process makes clear the word class assignment of the word to make it into adjective, adverb or another part of speech. Examples:

\begin{tabular}{|c|c|c|}
\hline Blends & Clippings & Reduplicatives \\
\hline Abolic - anabolic and steroids & Abs - abdominal muscles & $\begin{array}{l}\text { Ace boon-coon or boom-boom - one's good and loyal } \\
\text { friend }\end{array}$ \\
\hline Anticipointment - anti and disappointment & Abso-bloody-lutely & Artsy-craftsy - artistic \\
\hline Antsy - nervous (from ants and pants) & $\mathrm{Ag}$ and aggro modified from aggravated & Blah-blah - chattering \\
\hline Cokeaholic - cocaine and alcoholic & Gator - part of the tire, found on the highway & Bling-bling - fancy jewelry \\
\hline Gubbish - garbage and rubbish & Bluh-bloody & Bobo-drunk \\
\hline Lemme- let me & Cane and caine - cocaine & County-mounty - highway patrol officer \\
\hline Shwench - female freshman (from fresh wench) & Erb-marijuana & Doo-doo - fecal material \\
\hline (T) sup - What's up? & Perp - perpetrator (criminal) & Rusty-dusty - the buttocks \\
\hline Twack - a twelve pack of beer (twelve and pack) & Stats - statistics & Snail-mail-post office mail \\
\hline Hangry - hungry and angry & Umm (Amel, mel) - Amelia (smart, loving girl) & $\begin{array}{c}\text { Pooper-duper - super-duper (the greatest size or } \\
\text { excellence) }\end{array}$ \\
\hline
\end{tabular}

Conclusions. Slang is a kind of jargon marked by its rejection of formal rules. It is comparative freshness and being transitory. It regularly transgresses other social norms, making free use of taboo expressions. Slang arises as vocabulary which is used by a particular social group with specific aim, for example as a device for familiarizing a conversation. Slang comes in the form of new words with new meaning or old words with new meaning and word formation process plays an important role here. We have proposed generative models for blends, clippings, and reduplicatives, three dominant word formation phenomena in slang. In the further research we will prolong our findings and the most common ways of the slang formation.

\section{References:}

1. Dhita Novianti, Word Formation Analysis of English Slang Language on Deadpool Movie thesis. Jakarta: English Letters Department,
Faculty of Adab and Humanities, Staet Islamic University (UIN) Syarif Hidayatullah, P. 27-30. URL: https://docplayer.net/82417458Word-formation-analysis-of-english-slang-language-on-deadpoolmovie-a-thesis.html

2. Hatch E., Brown C. Vocabulary, Semantics, and Language Education. New York: Cambridge University Press, 1995. 480 p.

3. Nida Eugene A. Morphology. The Descriptive Analysis of Words (2nd Ed). USA: The University of America, 1970. 360 p.

4. Richard A. Spears American Slang Dictionary. $4^{\text {th }}$ ed.: McGraw Hill, 2007. $546 \mathrm{p}$.

5. Yule G. The Study of Language. USA: Cambridge University Press, 2010.319 p.

Пилипей Ю. А. Характеристика сленгоутворення: Blends, Clippings, Reduplicatives

Анотація. Мова може використовуватися як в усній, так і в письмовій формі залежно від їі контексту. Люди 
зазвичай використовують офіційну або стандартну мову у формальному контексті, тоді як у неформальному контексті зазвичай використовується неформальна. $€$ кілька мовних різновидів, які використовуються в неформальному контексті, і одним із них є сленг. Сленг здебільшого використовували злочинці, але нині багато спільнот висловлюють свої думки за допомогою сленгових лексем. Вони створюють багато нових слів і модифікують стандартні слова для внутрішнього використання. Цю статтю ми присвячуємо вивченню трьох найпоширеніших типів сленгоутворення. Ми пропонуємо три поширені словоформи в англійському сленгу: Blends, Clippings та Reduplicatives. Загалом моделі розкривають уявлення про генеративні процеси словотворення в сленгу - уявлення, які стають дедалі актуальнішими в контексті зростаючого поширення сленгу та нестандартних різновидів.

Досить часто сленгові слова можна зрозуміти через контекст, деякі культурні особливості, навіть якщо це новостворена сленгова лексема. Слухач завжди має слі- дувати підказкам, які допоможуть йому зрозуміти і розшифрувати те, що говорить носій мови, і не тільки він. Вживання сленгу поширюється далеко за межі країн, де офіційною мовою $є$ англійська.

Сама мова складається 3 деяких частин, таких як морфеми, слова, речення тощо. Кожна частина має свою функцію і правило. Зазвичай люди не замислюються, звідки власне ці мільйони слів. Ми, як користувачі мови, не надаємо уваги тому, як формується мова. На значення нової форми слова впливає процес утворення слова. Цей процес зазвичай називають процесом словотворення. У статті наводяться десять словотворчих способів формування слів та їх приклади. Для сленгоутворення було взято лише три поширених способи словоутворення, а саме: blends, clippings, reduplicatives. Для більш практичного дослідження методом вибірки були відібрані приклади цих сленгових лексем з Американського сленгового словника.

Ключові слова: сленг, сленгова лексема, словотворення, blends, clippings, reduplicatives. 